\title{
レーザーレター
}

\section{希ガスクライオターゲットを用いた レーザープラズマX線源}

\section{望月孝晏*.児玉了祐*・山中千代衛*}

\author{
（1986年11月10日 受理）
}

\section{Laser Plasma X-Ray Source Using Cryogenic Target of Inert Atomic Element}

\author{
Takayasu MOCHIZUKI, Ryosuke KODAMA*and Chiyoe YAMANAKA*
}

(Received November 10, 1986)

\begin{abstract}
$\mathrm{X}$-ray spectra from $0.53 \mu \mathrm{m}$ wavelength laser-produced plasmas are investigated for the photon energy range of $0.1 \sim 3 \mathrm{KeV}$ as a function of the atomic number $Z$. Several spectral humps are found to move towards higher energy side as $Z$ increases. These series of the humps are interpreted as, the transitions in $\mathrm{K}, \mathrm{L}, \mathrm{M}, \mathrm{N}, \mathrm{O}$ shells of ions. The square root of the photon energy at the spectral hump is found to be approximately linearly dependent on $Z$, suggesting that a semi-Moseley's law holds in the plasma x-rays. From this result liquid or solid cryogenic targets using Xenon or Krypton are found to be very useful as a practical $\mathrm{x}$-ray source. A preliminary experimental result of the cryogenic target is presented and a practical system is proposed.
\end{abstract}

レーザープラズマ $\mathrm{X}$ 線は高輝度, 且つ変換効 率*の高いことが近年の研究成果 ${ }^{1}$ として知ら れるようになり, その結果 X線リソグラフィー 光源や $\mathrm{X}$ 線顕微鏡光源, その他への応用が試み られている ${ }^{2}$ 。特に金属の多くは夕ーゲットとし て高いX線変換効率を持つことが知られてい る。しかしながらレーザープラズマ $\mathrm{X}$ 線の難点 としてはX線以外にプラズマ粒子やターゲット 材の蒸気が発生することであろう。長時間運転 が要求されるX線リソグラフィーや $\mathrm{X}$ 線顕微鏡 ではマスクやX線光学系への高速プラズマ粒子 による損傷や蒸気の付着が致命的となりうる。 プラズマ粒子は磁場によって防ぐことができる
が3! 中性の蒸気の付着を防止することは困難で ある。一方, これらの応用上最適な波長の X線 を強く発生する夕ーゲットはレーザープラズマ X線スペクトルの原子番号 $(Z)$ 依存性を知るこ とにより決定することができる。

本論文ではレーザープラズマX線源を実用化 するのに妨げとなりうるターゲット材の蒸着（ レーザースパッタリング）を起こさず，且つ X 線リソグラフィー光源として最適な波長の $\mathrm{X}$ 線 $(1 \sim 2.5 \mathrm{keV})^{2)}$ を放射するターゲット材とし て Kr，Xe ガスを低温にて液化又は固化したク ライオターゲットを用いることを提案する。 実際に上記の不活性ガスを固化してクライオタ

*大阪大学レーザー核融合研究センター（テ565 大阪府吹田市山田丘 2-6)

* Institute of Laser Engineering, Osaka University (2-6, Yamada-oka, Suita, Osaka, 565) 
ーゲットとしてパルスレーザーを照射する予備 実験の結果と実用的なシステム案を報告する。 既に望月等によりレーザー条件一定（波 長 $0.53 \mu \mathrm{m}$, 強度 $10^{14} \mathrm{~W} / \mathrm{cm}^{2}$, パルス巾 $1 \mathrm{n} \mathrm{sec}$, 入射 角 $54^{\circ}$ ) の時, $0.1 \sim 1.5 \mathrm{keV}$ の領域の X線を発 生するX線変換効率は原子番号の増大と共に増 加していくがゆるやかな振動構造を持つことが 知られている1)。だが, 今回はレーザー強度 $10^{14}$ $\mathrm{W} / \mathrm{cm}^{2}$, パルスウ $1 \mathrm{nsec}$ とし,レーザー入射角は $35^{\circ}$ に固定した。ビームスポット径は 150～200 $\mu \mathrm{m}$ とした。上記の X線波長領域 $(0.1 \sim 1.5 \mathrm{keV})$ に対しては Ref. 1 と同じく 10 チャンネルの フィルター付高速応答 $\mathrm{X}$ 線ダイオード $(\mathrm{XRD})$ のセットを用いて X線スペクトル強度を評価し た。1.0〜2.0 keVの領域に対してはTlAP**結 晶とKODAKのDirect Exposure Film(DEF) ${ }^{4}$ とを組み合わせた $\mathrm{X}$ 線結晶分光器によるスペク トル分布の評価をおこなった。1.5〜3 keVに対 しては膜厚 $45 \mu \mathrm{m} の \mathrm{Be}$ フィルターと組合わせた X R Dによる強度の評価をおこなった。 Ref. 1 と同様にX 線スペクトル強度の原子番号依存 性が0.1〜 $3 \mathrm{keV}$ の広範囲に渡り求められた ${ }^{5}$ 。 その結果, レーザー入射角度 $54^{\circ}$ に比べ变換効 率は全体に増加していることがわかった。これ はレーザー光がより密度の大きい領域に進入し, そのためプラズマによるレーザーエネルギーの 吸収が増加することによると考えられる。各原 子番号 $(Z)$ のターゲットからのスペクトルは特 有な山を持ち，それらの山の位置の平方根 $\sqrt{h \nu}$ を $Z$ の変化について追跡すると Fig.1のように 網線で結ぶことができた ${ }^{5}$ 。太い実線はスペクト ル強度の山の部分を $\mathrm{X}$ 線光子エネルギー領域で 示したものである。但し山の頂上の $1 / 2$ 以上の強 度を持つ領域を基準にして決めた。これらの網 線で示す山（スペクトル強度大の部分）の系列 は発生したイオンの電子軌道 $\mathrm{K}, \mathrm{L}, \mathrm{M}, \mathrm{N}, \mathrm{O}$ 殼 での遷移によるX線に対応しており，レーザー プラズマでの輻射も古典的なモーズレーの法則 ${ }^{6 !}$ と同様な関係 $Z \propto \sqrt{h \nu}$ の值で比較的強く輻射が 生じていることがわかる。ここで $h \nu$ は光子の エネルギーである。求められた関係は上記のよ

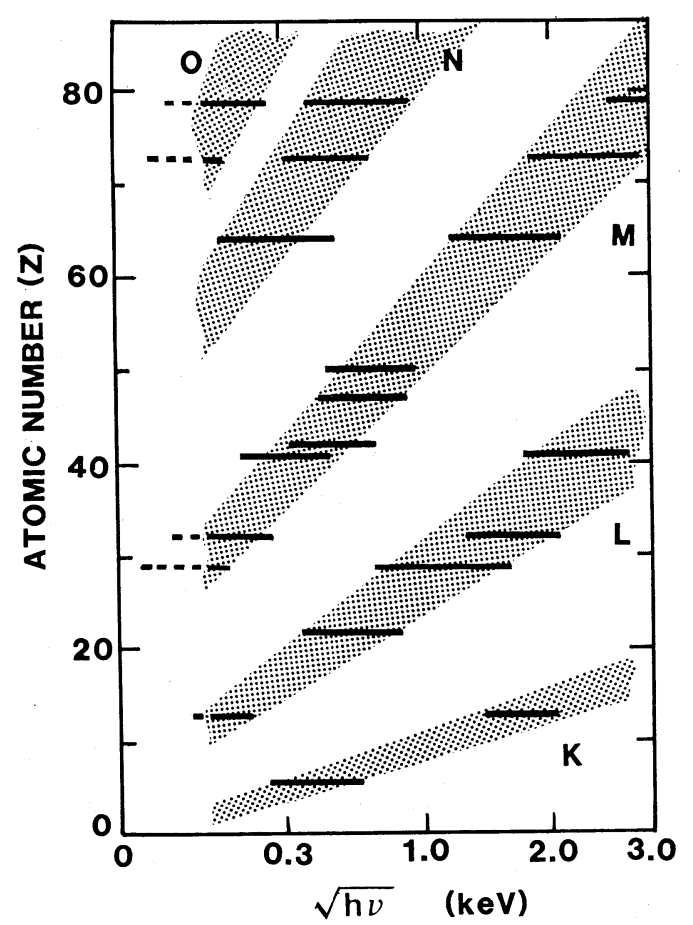

Fig. 1 Positions of the X-ray spectral humps as a function of the atomic number $Z$. Solid lines show the positions of the hump.

うな限られたレーザー条件のもとで得られたも のであるが, このような $Z$ 依存性のふるまいは 原子構造に基づくものであり，スペクトル強度 の山の高さは変化するにしても生成されたプラ ズマの温度・密度分布によってあまり変化しな いと考えられる。また使用したレーザー条件はレ 一ザープラズマX線光源を実用化するうえで期 待されるパラメーターにほぼなっており ${ }^{2 !}$, 応用 上かなり一般性があると考えられる。このよう な擬似モーズレ一の法則から，逆に欲しいX線 の光子エネルギーを決めればこの光子領域を強 く輻射する元素を容易に予想することができる。 ここでX線りソグラフィ一用に望まれる $1 \sim 3$ $\mathrm{keV}$ の X 線を比較的効率よく輻射する夕ーゲッ トとして化学的に不活性な元素を考えると Xe $(Z=54), \mathrm{Kr}(Z=36)$ がFig. 1 より最も良 いことがわかる。Xeは $1 \mathrm{keV} に$ 近いX線を $\mathrm{Kr}$ より強く輻射する。希ガスをガスパフとして真 


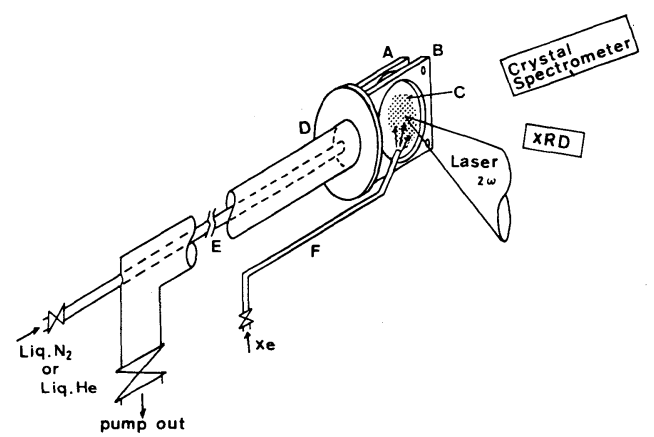

Fig. 2 Schematic View of the experiment set-up for a cryogenic target

A, B: Holder for a substrate,

C: Crystal substrate

D: Cryo-base plate,

E: Transfer tube for liq. $\mathrm{N}_{2}$ or liq. He.

F: Nozzle for inert atomic gas

空中に放出し，そこにレーザーを集光する方法 では充分に大きな粒子密度を得ることが困難な 為, エネルギー密度が低く充分な $\mathrm{X}$ 線放射輝度 を得られない。またスケール長の長いプラズマ が生成されるためレーザー光との非線形相互作 用によりプラズマ不安定性が生じやすい。幸い これらの希ガスは比較的容易に液化, 固化が可 能であるため***固体又は液体のターゲットと して使用可能である。また入手も困難ではない。 このようなターゲットを希ガスクライオターゲ ットと呼ぶことにする。これらのターゲットを 用いれば空材やマスクへのターゲット材の蒸着 の問題は解決されよう。

我々はXe $(Z=54)$ の X線変換効率とスペク トル形状を調べるため Fig. 2のような実験装置 を用い予備実験をおこなった。クライオスタッ トとしては温度可変制御のできる Continuous Flow Cryostatを用いた。*㹸結晶基板 Cを金 メッキした金属板 AとBによりインジウムを介 して狭み込み, これらは台座 Dに固定されてい る。結晶板としては, 原子番号が Xe と一つ違 いで, 且つ低温で熱伝導が, 比較的よく, 可視 一赤外光に対して透明な $\mathrm{Cs}(Z=55)$ I $(Z=53)$ 結晶を用いた。台座 Dは図中の二重円筒の内部 の細管を通って放出, 気化される液体へリウム 又は液体窒素によって冷却される。したがって
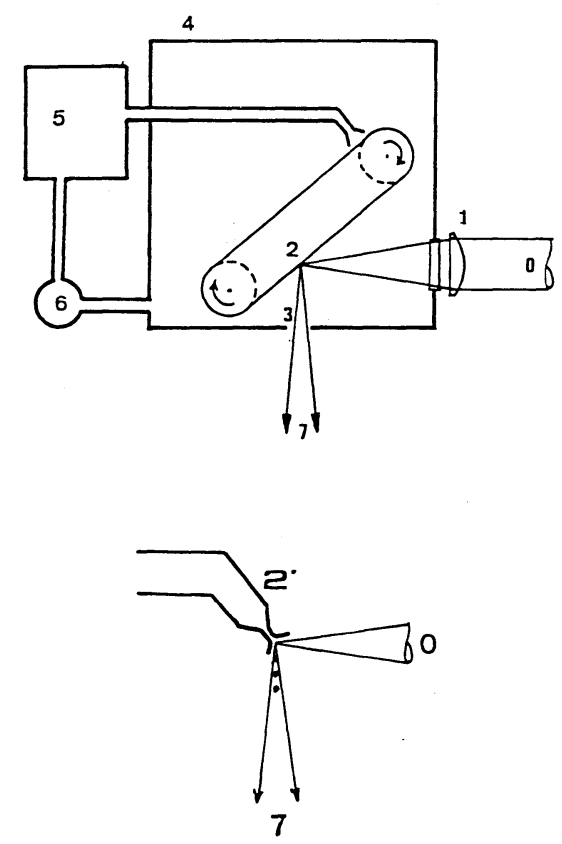

Fig. 3 Example of laser-plasma x-ray source using a cryogenic target of inert atomic element.

1 : Laser focusing optics, 2 : Cryotarget, $2^{\prime}$ : Nozzle $3: \mathrm{X}$-ray exit, 4: Vacuum chamber, 5: Refrigerator 6 : Evacuation and recirculation pump, 7 : X-ray

結晶基板も充分に冷却される。基板の温度は温 度センサーによってモニターされ, 台座Dに取 付けられたヒーターを制御することにより温度 を任意の值で一定に保つことができる。充分に 冷却された基板に向けて細管 $\mathrm{F} の$ 先端のノズル より $\mathrm{Xe}$ ガスをゆっくり真空中に噴出すると, 基板上には液体又は固体の Xe層が形成される。 右側より波長 $0.53 \mu \mathrm{m}$ のパルスレーザー光がFig. 1 のデータ取得と同じ条件で集光照射され, 発 生したX線は結晶分光器, X R D より観測さ れた。基板上のXe層の厚さは容易に数 $\mu \mathrm{m}$ 数 十 $\mathrm{m}$ にすることができる。観測されたスぺク トルの位置, X線変換効率の值は予想連りのも のであった。詳しくは別の論文で報告する予定 である。

Fig. 3 はクライオターゲットを用いたレーザ 
ザープラズマ X線源の一例である。希ガスを液 化, 又は固化したクライオターゲットはベルト 又は同等な機能を持つ手段によりレーザー照射 部へ運ばれ照射される。レーザー加熱により気 化された希ガスは充分に温度の高いチャンバー 壁には付着せずガスとして回収され, 再度液化 又は固化される。このような循環方式を取れば ターゲット材料を外部から常に供給することな く長時間運転可能となろう。また液滴にして噴 出, 又は落下させ, これをレーザーで照射すれ ば後続のターゲット材を不要に予備加熱するこ そを防ぐことができよう。

レーザープラズマ $\mathrm{X}$ 線を $\mathrm{X}$ 線リソグラフィー 等へ応用する場合の最適なレーザー条件及び夕 一ゲットの選択方法は最近明らかにされつつあ るが, 今回X線スペクトルのターゲット原子番 号依存性が擬似モーズレーの法則に従うことか ら $1 \sim 3 \mathrm{keV}$ 領域のX線を比較的効率よく（ 10\%）輻射するターゲット材としてXe, Kr, ガ スを液化又は固化したクライオターゲットが有 効であることがわかった。予備実験で調べたと ころ予想通りの X線強度を上記 X 線領域で与え ることがわかった。これらのクライオターゲッ トの使用によってX線空材やマスクへのターゲ ット材の蒸着の問題は解決されよう。クライオ ターゲットを使用することによる上述の特徵は $\mathrm{X}$ 線リソグラフィーのみならず他の応用上も有 用であろう。
注)

*) 慣習としてレーザーエネルギーから X線エネルギ 一へのConversion efficiencyの和訳として用いら れているが要するに発生効率である。

**) Thallium Acid Phthalate.

***) キセノン; 液化点 $-107.1^{\circ} \mathrm{C}$, 固化点 $-111.9^{\circ} \mathrm{C}$ クリプトン; 液化点 $-152.9^{\circ} \mathrm{C}$, 固化点 $-156.6^{\circ} \mathrm{C}$

****) The Oxford Instrument Co. Ltd, Type CF 104 を改造した。

\section{参 考 文 献}

1) T. Mohizuki et al: Phys. Rev. A33, 525 (1986) 及びこの論文中に引用されている文献。

2 ）望月孝晏：大阪大学レーザー核融合センター, Research Report ILE 8607P (June, 1986)

3 ）望月孝晏他：レーザー学会第 6 回学術講演予稿集 p. 143, 1986.

4 ) P. D. Rockett, C. R. Rird, C. J. Hailey, D. Sullivan, D. B. Brown and P. G. Burk halter : Appl. Optics 24, 2536 (1985).

5 ) T. Mochizuki and C. Yamanaka : (to be published in SPIE 733-05 (1986)).

6) H. G. J. Moseley: Phil. Mag. 27, 703 (1914). 